\section{Australian Journal of \\ Crop Science}

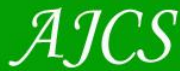

ISSN:1835-2707

AJCS 13(03):444-451 (2019)

doi: 10.21475/ajcs.19.13.03.p1390

\title{
Biochemical metabolism of two cultivars of cowpea treated with 24-Epibrassinolide and subjected to saline stress
}

\section{Kerolém Prícila Sousa Cardoso ${ }^{1 *}$, Susana Silva Conceição ${ }^{1}$, Ana Ecídia de Araújo Brito ${ }^{1}$, Jéssica Taynara da Silva Martins ${ }^{1}$, Liliane Corrêa Machado ${ }^{1}$, Thays Correa Costa ${ }^{1}$, Glauco André dos Santos Nogueira ${ }^{1}$, Vitor Resende do Nascimento ${ }^{1}$, Rafael Pimentel Prata da Silva ${ }^{1}$, Rafael Costa Paiva ${ }^{1}$, Antônio Vinícius Correa Barbosa $^{2}$, Ricardo Shigueru Okumura ${ }^{3}$, Cândido Ferreira de Oliveira Neto ${ }^{1}$}

\author{
${ }^{1}$ Institute of Agrarian Sciences, Laboratory of Biodiversity Studies of Upper Plants, Federal Rural University of \\ Amazonia, Campus Belém, Pará, Brazil \\ ${ }^{2}$ Institute of Ciberespacial, Federal Rural University of Amazonia, Campus Belém, Pará, Brazil \\ ${ }^{3}$ Federal Rural University of Amazonia, Campus Parauabepas, Pará, Brazil
}

*Corresponding author: ecidiabrito@hotmail.com

\section{Abstract}

We aimed to evaluate the changes in biochemical metabolism generated by salt stress and to investigate the effect of brassinosteroids in mitigating of this stress on two cultivars of Vigna unguiculata L. We used a completely randomized experimental design in a $2 \times 3 \times 3$ factorial scheme, using two cultivars of cowpea (BRS Guariba and BR3 Tracuateua - moderately tolerant and sensitive to salinity, respectively), three concentrations of brassinosteroids $(0,0.2$ and $0.4 \mu \mathrm{M} \mathrm{Br})$ and three concentrations of $\mathrm{NaCl}$ $(0,50$ and $100 \mathrm{mM} \mathrm{NaCl})$, with four replicates. The following evaluations were carried out: relative water content, electrolyte leakage, nitrate levels, nitrate reductase activity, free ammonium, total soluble amino acids, soluble proteins, glycine betaine and proline. The results showed that salinity at $100 \mathrm{mM}$ affected the nitrate reductase enzyme activity, the relative water content, total soluble amino acids and soluble proteins for cultivars BR3 Tracuateua, and BRS Guariba, but the 24-epibrassinolid attenuated the effects of salinity for these variables. The concentration of $0.2 \mu \mathrm{M}$ of $\mathrm{Br}$ increased $55 \%$ and $20 \%$ in proline and glycine betaine contents, respectively, in both of cultivars. The plants under stress saline and $0.2 \mathrm{mM}$ of 24 -epibrassinolid, presented $42 \%$ and $58 \%$ reductions in electrolyte leakage of BR3 Tracuateua and BRS Guariba cultivars, respectively. The concentrations of ammonium were slightly varied. Therefore, the application of $0.2 \mu \mathrm{M}$ of 24 -epibrassinolid caused a greater acclimatization of the cultivars, being the BR3 Tracuateua (sensitive to salt) cultivar more expressive in most treatments.

Keywords: BRS Guariba, BR3 Tracuateua, hormone, nitrogen, salinity.

Abbreviations: $\mathrm{Br}$ _Brassinosteroids; DAS_Day after sowing; CRD_Completely randomized design; $\mathrm{Cv}$ _Cultivate; EBL_Active form of brassinosteroids; EL_Electrolyte leakage; TW_Turgid weight; FW_Fresh weight; DW_Dry weight; RWC_Relative water content.

\section{Introduction}

The plants are affected by various of stress combinations in nature (Suzuki et al., 2014), like biotic and abiotic stress factors, limiting agricultural productivity, causing the loss of plant biomass and negative effects on growth, development, and consequently production of the vegetable (Nascimento et al., 2011). Among the abiotic stresses, salinity is among those that cause more damages to crops by reducing the osmotic potential of the soil, causing the physiological drought of plants invalidating a number of metabolic processes, as well as economic performance of yields (Major and Sales, 2012).

The cowpea bean is a crop of great potential and its grains are among the main sources of protein and energy for man, consisting of a rich food source with high fiber content, vitamins, minerals and a low amount of lipid (Frota et al., 2008). However, it is strongly affected by saline stress, which promotes major metabolic disturbances and nutritional disorders in the specie (Hasegawa, 2013).

The saline soils impair the absorption of the nitrogen $(N)$ mineral (Zahran, 1999) affecting several stages of metabolism of this element which is limiting to plant growth (Willians; Miller, 2001) and reducing protein synthesis (Frechill et al., 2003). In response to excess salts in the soil, the plants restrict the absorption and/or transport of ions from root to shoot by amplifying their biochemical mechanisms of tolerance to this adverse condition (Wei et al., 2003).

In this context, the study to find alternatives for adaptation of plants to the simultaneous action of multiple stress factors is highly demanded (Suzuki et al., 2014). The scientific evidences have pointed the activities of several hormones related to the joint response of plants to stress, including ethylene, abscisic acid, salicylic acid and brassinosteroids (Sharma et al., 2007). The brassinosteroid 
$(\mathrm{Br})$ are a new class of phytohormones with polyoxygenated structure endowed with pronounced growth-regulatory activity (Zullo and Adam, 2002).

This growth regulator is integrated to various physiological processes of positive responses to stress (Anuradha and Rao, 2003). Thus, the 24-epibrassinolid (EBL - active form of brassinosteroids) (Adam and Marquardt, 1986), can generally contribute positively on the physiological and biochemical parameters, improving the response to stress and change the structures and permeability of cells (Hamada, 1986).

Thus, the use of hormones to attenuate plant stresses are important tools to understand the metabolic processes involved in adapting the species. Because of its environmental, social and economic importance, study on cowpea in regions with saline soils has become fundamental in the scientific perspective. Therefore, addition of plant hormones on cultivation and value of cowpea in unfavorable areas is important.

There are many studies on the effects of salinity on the biochemical variables of cowpea. Besides, the action of the brassinosteroids to mitigate the harmful effects of this stress has been widely known. However, they do not clearly involve the processes of nitrogen metabolism. Therefore, this work focuses the nitrogen metabolism which contributes to the current knowledge on salt stress and the action of brassinosteroids on this specie of importance economic, social and environmental.

Therefore, the aim of this work was to evaluate the changes in biochemical metabolism generated by salt stress in two cowpea cultivars and to investigate the effect of brassinosteroids in mitigating the salt stress, in which, we hypothesized that the brassinosteroids will attenuate the deleterious effects of saline stress.

\section{Results}

\section{Relative water content and electrolyte leakage}

Through the results of this study it was possible to note that the RWC presented a general tendency of reduction with the increasing levels of salinity. The higher $\mathrm{NaCl}$ concentration significantly $(p<0.05)$ reduced the water content and electrolyte leakage by $50 \%$ and $57 \%$, respectively, in both cultivars compared to the control (Fig. 1 A).

We observed that plants under stress of $\mathrm{NaCl} 100 \mathrm{mM}$ showed partial recovery of relative water content, when treated with 24-epibrassinolid. It was more evident in the concentration of $0.4 \mu \mathrm{M}$, with $43 \%$ and $33 \%$ of increase $(p<$ 0.05 ) in both cultivars, compared to plants under the highest level of saline stress (Fig. 1 A).

Increasing levels of salinity promoted gradual increases in electrolyte leakage (EL) when compared to control plants under $\mathrm{NaCl}$ stress. So, the $100 \mathrm{mM}$ salt treatment increased the EL significantly $(p<0.05)$ by $97 \%$ and $62 \%$ in the leaf tissue of cultivars BR3 Tracuateua and BRS Guariba, respectively (Fig. 1 B). Plants under stress of $100 \mathrm{mM} \mathrm{NaCl}$, presented significant reductions $(p<0.05)$ of $42 \%$ and $58 \%$, when nourished with $0.2 \mathrm{mM} \mathrm{Br}$, for BR3 Tracuateua and BRS Guariba cultivars, respectively, when compared to plants treated with only $100 \mathrm{mM} \mathrm{NaCl}$ (Fig. 1 B).

\section{Content of $\mathrm{NO}_{3}^{-}$and nitrate reductase activity}

There was a significant $(p<0.05)$ reduction of $38 \%$ for the $\mathrm{cv}$. BRS Guariba and $50 \%$ for the cv. BR3 Tracuateua in $\mathrm{NO}_{3}$ levels in saline stress treatments subjected to $100 \mathrm{mM} \mathrm{NaCl}$ compared to the control treatment (Fig. $2 \mathrm{~A}$ ). The results indicated a possible attenuation of saline stress when the $V$. unguiculata plants were treated with brassinosteroids under $100 \mathrm{mM} \mathrm{NaCl}$, showing that the nitrate levels cv. BRS Guariba was increased significantly $(p<0.05)$ by $40 \%$ for the two concentrations of $\mathrm{Br}$ and the cV. BR3 Tracuateua by $33 \%$ for the concentration of $0.2 \mu \mathrm{M}$ of $\mathrm{Br}$ and $30 \%$ for the concentration of $0.4 \mu \mathrm{M}(\mathrm{Br})$.

In contrast, we observed that cultivar BR3 Tracuateua showed to be more expressive when submitted to $0.2 \mu \mathrm{M}$ $\mathrm{Br}$, presenting values similar to those of the control (Fig. 2 A).

There was a reduction in the enzymatic activity of nitrate reductase as the saline stress was increased. At the concentration of $100 \mathrm{mM}$ a significant $(p<0.05)$ reduction of $87 \%$ for cv. BRS Guariba and $98 \%$ for cv. BR3 Tracuateua was occurred, compared to the control treatment (Fig. 2 B).

When the cultivars were treated with the two levels of the hormone they showed higher activity of nitrate reductase in relation to the $\mathrm{NaCl}$ concentrations. However, a higher recovery was observed in the plants treated with 0.2 and 0.4 $\mu \mathrm{M}$ under $50 \mathrm{mM} \mathrm{NaCl}$ stress, in which the BRS Guariba was significantly $(p<0.05)$ increased by $48 \%$ and $21 \%$ for two hormone levels, respectively. The increase in nitrate reductase BR3 Tracuateua was $33 \%$ and $68 \%$, according to the level of hormones studied (Fig. 2 B).

\section{Ammonium, amino acid content and soluble proteins}

It was observed that the ammonium concentration suffered variations in leaf tissue of both cowpea cultivars under the effect of salt stress. As shown in Fig $3 \mathrm{~A}$, the values found in plants under $100 \mathrm{mM} \mathrm{NaCl}$, were slightly higher than the control $-14 \%$ and $17 \%$ to cultivate BR3 Tracuateua and BRS Guariba, concomitantly (Fig. 3 A).

Application of $\mathrm{Br} 0.2 \mu \mathrm{M}$ on cultivar BR3 Tracuateua showed significant increases of $36 \%$ in ammonium concentration compared to the control. In a divergent way, under the effect of the same treatment, there was $37 \%$ reduction in ammonium concentration in the leaf tissue of BRS Guariba (Fig. $3 \mathrm{~A})$.

The results showed a reduction of amino acid content by $32 \%$ and $43 \%$ in BRS Guariba and $33 \%$ and $53 \%$ for BR3 Tracuateua in saline stress of $50 \mathrm{mM}$ and $100 \mathrm{mM}$, respectively, compared to the control. The concentrations of brassinosteroids 0.2 and $0.4 \mu \mathrm{M}$ exerted great influence on the attenuation of acclimatization of salinity cultivars (Fig. 3 B).

It was observed that application of $0.2 \mu \mathrm{M}$ of $\mathrm{Br}$ on BR3 Tracuateua under stress of $100 \mathrm{mM} \mathrm{NaCl}$ causes a significant increase $(72 \%)$ in amino acid content, compared to control plants. In BRS Guariba, there was slight variation in concentration of amino acid content, although they have also exhibited increase of $22 \%$ in the studied variable, as effect of the same treatment (Fig. 3 B).

Among the results, soluble protein contents were decreased in saline concentrations of $100 \mathrm{mM}$, presenting a decrease of $66 \%$ and $77 \%$ for BR3 Tracuateua and BRS Guariba, 


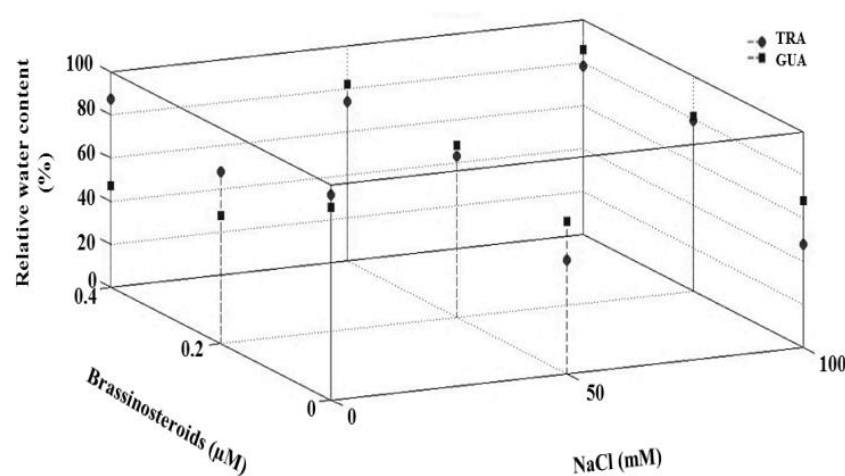

A

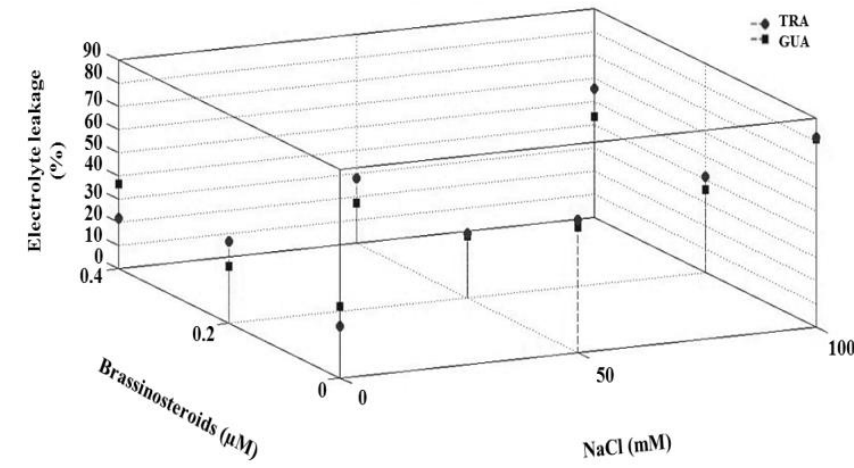

Fig 1. Relative water content (A) and Electrolyte leakage (B) in leaves of cultivars BRS Guariba and BR3 Tracuateua Vigna unguiculata (L.) Walp. grown in nutrient solution as a function of increasing concentrations of brassinosteroids $(\mathrm{Br})$ and $\mathrm{NaCl}$.

$\mathbf{A}$
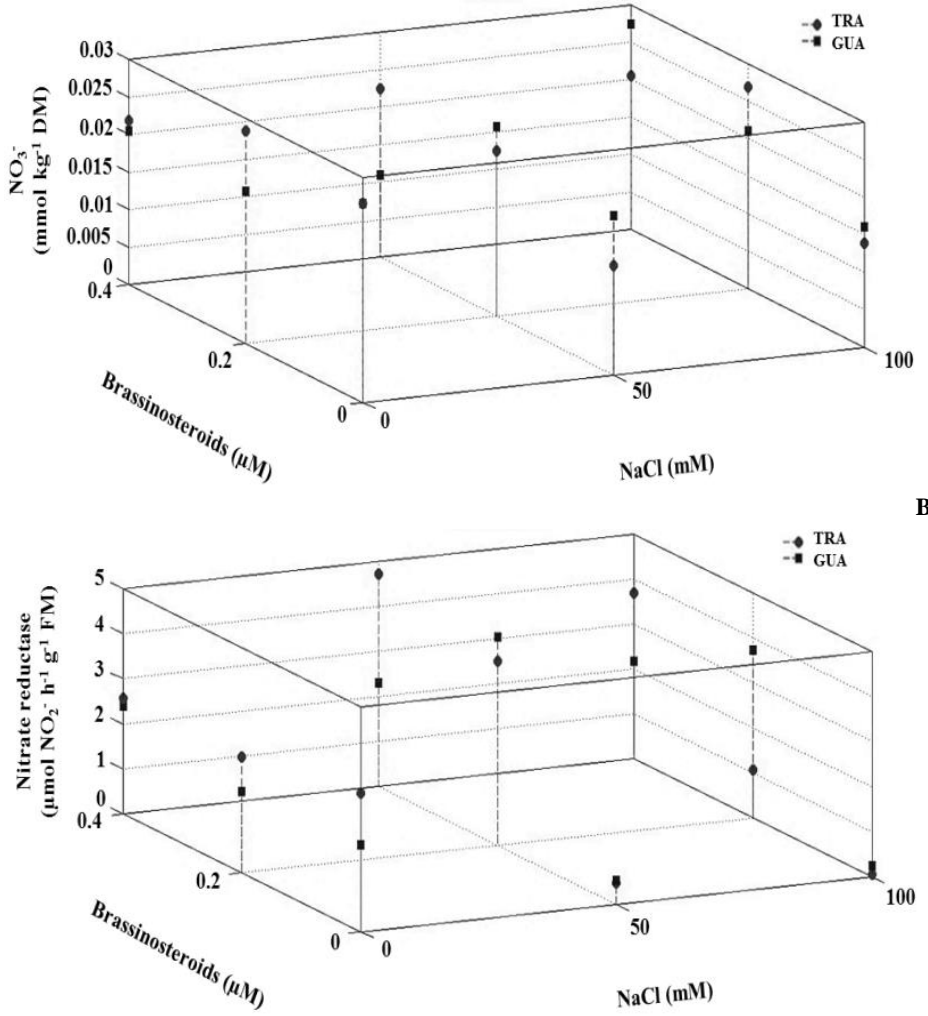

Fig 2. Nitrate content $(A)$ and Nitrate reductase activity (B) in leaves of cultivars BRS Guariba and BR3 Tracuateua of Vigna unguiculata (L.) Walp. grown in nutrient solution as a function of increasing concentrations of brassinosteroids ( $\mathrm{Br}$ ) and $\mathrm{NaCl}$. 


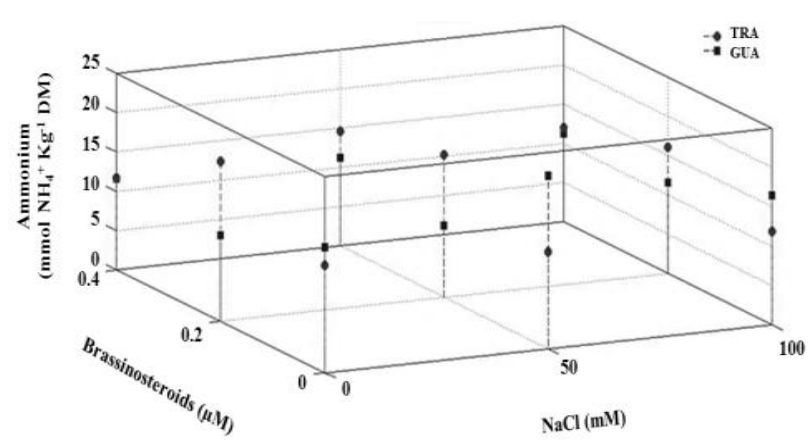

A
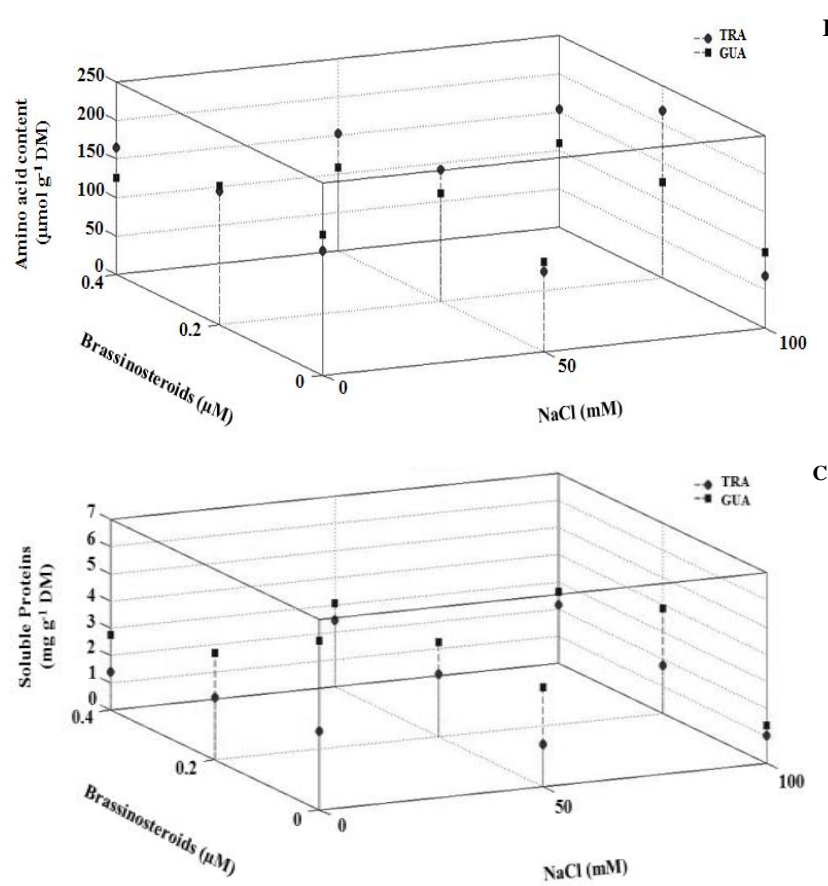

Fig 3. Ammonium (A), Amido acid (B) and Soluble proteins contents (C) in leaves of cultivars BRS Guariba and BR3 Tracuateua of Vigna unguiculata (L.) Walp. grown in nutrient solution as a function of increasing concentrations of brassinosteroids $(\mathrm{Br})$ and $\mathrm{NaCl}$.

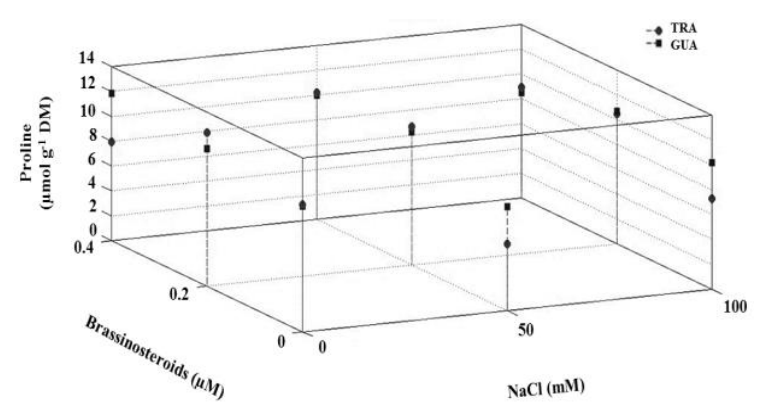

A

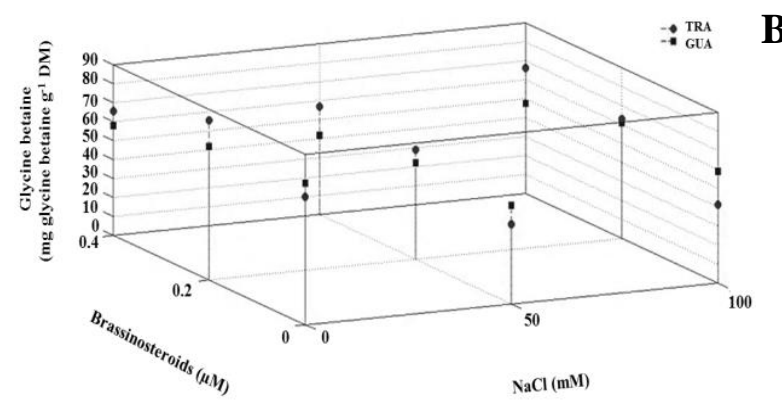

Fig 4. Proline contents (A) and Glycine betaine contents (B) in leaves of cultivars BRS Guariba and BR3 Tracuateua of Vigna unguiculata (L.) Walp. grown in nutrient solution as a function of increasing concentrations of brassinosteroids $(\mathrm{Br})$ and $\mathrm{NaCl}$. 
respectively, when compared to control plants. From the results found in this study, the concentrations of brassinosteroids are considered to have partially reversed effects. The leaf tissue of cv. BRS Guariba plants submitted to saline stress under treatment with $0.2 \mu \mathrm{M}$ of $\mathrm{Br}$ showed high protein content (by 64\%), compared to plants under stress by $100 \mathrm{mM} \mathrm{NaCl}$ (Fig. $3 \mathrm{C}$ ).

However, the highest concentrations of $\mathrm{Br}(0.4 \mu \mathrm{M})$ did not show superior effects on proteins compared to 0.2 in both analyzed cultivars, under stress of $100 \mathrm{mM} \mathrm{NaCl}$. This dosage of the hormone $(0.4 \mu \mathrm{M})$ only increased $47 \%$ and $52 \%$ for BR3 Tracuateua and BRS Guariba, concomitantly (Fig. 3 C).

\section{Compatible osmolytes}

The highest concentration of $\mathrm{NaCl}(100 \mathrm{mM})$ decreases the levels of proline and glycine betaine, where under the effect of such treatment proline concentration of leaves was $42 \%$ lower than control cultivar BR3 Tracuateua. Under the effect of the same concentration of $\mathrm{NaCl}$, we observed concentration of only $11 \%$ osmolytes in leaf tissue of BRS Guariba, when compared to control plants (Fig. 4 A).

However, plants under saline stress of $100 \mathrm{mM}$ treated with $0.2 \mu \mathrm{M} \mathrm{Br}$ showed a considerable increase of proline and glycine betaine, by $55 \%$ and $20 \%$, in foliar tissue of the $\mathrm{cv}$. BR3 Tracuateua and BRS Guariba, respectively (Fig. 4 A).

Thus, it is considered that the concentration of $0.2 \mu \mathrm{M}$ induces tolerance in plants under $\mathrm{NaCl}$ stress. The results show that treatment with only $0.2 \mu \mathrm{M}$ of brassinosteroid induced increases in proline content in the leaves of both cultivars exceeding those observed in control plants (39\% cV. BR3 Tracuateua and 32\% cv. BRS Guariba) (Fig. 4 A).

Under saline stress of $100 \mathrm{mM}$, we observed decreases in glycine betaine content in the leaf tissue of cv. BRS Guariba by $21 \%$ when compared to that observed in the control treatment. However, the cv. BR3 Tracuateua, was considerably affected by saline stress, in which the glycine betaine content was reduced by $42 \%$, when compared to the control treatment (Fig. 4 B).

The application of brassinosteroids induced an increase in glycine-betaine concentrations in both cultivars, showing that this hormone acted in the induction of the plant to acclimation to saline stress. However, it was more evident in cv. BRS Tracuateua at saline stress of 50 and $100 \mathrm{mM}$ treated with $0.4 \mu \mathrm{M}$, presenting increases of $36 \%$ and $52 \%$ in the content of this osmolyte for the concentrations of $\mathrm{NaCl}$, respectively, compared to the foliar tissue of plants exclusively treated with 50 and $100 \mathrm{mM} \mathrm{NaCl}$ (Fig. 4 B).

The exclusive treatment with $0.2 \mu \mathrm{M}$ brassinosteroids was the one that best induced increases in glycine concentration in both cultivars. Under this concentration of $\mathrm{Br}$ increases in glycine concentrations were $23 \%$ (cv. BR3 Tracuateua) and $18 \%$ (cv. BRS Guariba) higher than the control plants and 53\% (cv. BR3 Tracuateua) and 37\% (cv. BRS Guariba) higher compared to plants under stress by $100 \mathrm{mM} \mathrm{NaCl}$ (Fig. 4 B).

\section{Discussion}

The results suggest that the supplementation of saline solution with 24-epibrassinolide increased the tolerance of plants to saline stress, by which it promoted improvements in the water status evidenced by the increase of RWC in both cultivars studied. Possibly this hormone alters the leaf osmotic potential, making the cell charge more negative. This could also be attributed to the influence of $\mathrm{Br}$ on further accumulation of compatible solutes as it was found in this research. Similar results were also found by Furtado et al. (2014), in which increase of saline level of irrigation water promoted a linear reduction of the relative water content in Vigna unguiculata L. (Walp.) plants, presenting a decrease of $2.36 \%$ by unit increment of the electrical conductivity of the irrigation water.

The attenuation of saline toxicity in the presence of $\mathrm{Br}$ was resulted from the probable reduction of $\mathrm{Na}^{+}$content in the cellular tissues and by the possible dilution effect of the toxic salts, since the hormone increased the water content by the greater accumulation or synthesis of compatible solutes in the plant as reported in this study.

Although our study does not report the functioning of $\mathrm{H}^{+}$ATPase in conferring the exclusion of $\mathrm{Na}^{+}$ions in cowpea plants, but the possible action of brassinosteroids may be attributed to high energy availability to the greater efficiency of these pumps, giving the plants a greater inducement to acclimation to salt stress by exclusion of $\mathrm{Na}^{+}$ions of the cellular compartments.

The reduction of the nitrate concentration in plants treated with $\mathrm{NaCl}$ may also be related to the competition of ions $\mathrm{Cl}^{-}$ by conveyors of $\mathrm{NO}_{3}^{-}$(Ogawa et al., 2000) and/or inactivation of nitrate transporters by the toxic effects of ions (Lin et al., 2002), affecting nitrogen absorption because $\mathrm{NO}_{3}{ }^{-}$is the main form that is absorbed by plants, which is reduced to ammonium by sequential reduction reactions. The sequential reduction reactions is catalyzed by the enzymes nitrate reductase, glutamine synthetase and glutamate synthase, leading to the synthesis of amino acids (Debouba et al., 2007).

The activity of nitrate reductase was directly affected by saline stress and this stress leads to water deficiency. This enzyme is reduced due to the low flow of water by the transpiratory current and the consequent decrease of nitrate flow to the leaves (Alves, 2010).

According to Moro (2012), nitrate reductase is often reduced in activity when subjected to high levels of water stress. Oliveira (2010) pointed out another characteristic of the enzyme to use of energy from photosynthesis, which regulates the supply of carbon skeletons for incorporation of nitrogen into amino acids.

The free ammonium accumulation in plant tissue in high concentrations of $\mathrm{NaCl}$ may be attributed to their direct uptake, nitrate reduction, deamination of nitrogenous compounds by photorespiratory cycle or by biological fixation (Horchani and Ashi-Smiti, 2010). Several authors have shown that plants under salt stress conditions promote an increase in the activity of the enzymes glutamine synthetase (GS) and glutamate synthase (GOGAT) involved in ammonium assimilation, which are assimilated on the alternative route glutamate dehydrogenase (GDH) (Carvalho, 2012; Taiz and Zeiger, 2013).

The decrease in amino acid levels due to $\mathrm{NaCl}$ stress can be resulted from the reduction in protein synthesis and the association of mRNA (messenger RNA) with polysomes (Bagga et al., 2005). In this regard, it is considered that this reduction is closely related to the lower synthesis of proteins in stressed plants, the fact proven in this study through a considerable reduction in protein concentration. 
In a study of two cultivars of cowpea in salt stress conditions, Praxedes et al. (2009) observed that there was an increase in the concentration of amino acids. According to these authors, a drain was occurred in response to accumulated excess nitrogen content due to reduced plant growth. This result; however, differs from the present study. It is considered that the experimental conditions and the phenological stage of the plants worked by the above mentioned authors have influenced the opposite results that have been obtained in this research.

In this study, the biochemical changes are occurred as the greater regulation in the synthesis of amino acids in the presence of the hormone, being inferred that the brassinosteroid contributed to the carbon and nitrogen ratio $(\mathrm{C} / \mathrm{N})$ balance in the plant in favor of the nitrogen.

To protein synthesis reduced when plants were subjected to the salt stress due to salinity to affect many metabolic pathways. It also promotes water stress, in which there is a change in the metabolic behavior of the plant degrading the proteins to amino acids. This process is an important indicator of physiological state of the plant (Demiral and Turkan, 2006).

However, possibly the concentrations of $\mathrm{Br}$ contributed to the synthesis of the proteins, keeping water levels in the leaves, answering with the cellular osmotic balance. In addition, some proteins that involve in hydrophilic interaction with cellular macromolecules may have been synthesized to establish the metabolism and act in the recovery from damage caused by stress (Streit et al., 2005). The increases in proline content were possibly generated by disturbances in the metabolism of proteinases, probably to maintain the water potential of the leaf. Increase of the content of this amino acid induces the synthesis and the accumulation of compatible solutes in the cytosol, as a way to balance the Osmotic pressure promoted by the excess of toxic ions $\left(\mathrm{Na}^{+}\right.$and $\left.\mathrm{Cl}^{-}\right)$in the vacuole. This stabilizes the membranes and to maintain the conformation of proteins, preventing the dehydration of the cytosol (Kishor et al., 2005; Munns and Tester, 2008).

The increase of glycine betaine probably occurred to protect plant metabolism, since glycine betaine can act as a compatible solute by maintaining the water balance between the plant cell and the environment, stabilizing the macromolecules (Carlin and Santos 2009). The metabolic pathways, by which brassinosteroids act on the plant and gives the induction of tolerance to salt stress, are still not well-understood. However, from our results, it is considered that the hormonal regulation is involved in the synthesis of compatible osmolytes such as proline and glycine betaine.

\section{Materials and methods}

\section{Plant material and culture conditions}

The experiment was conducted from July to August 2015 in the greenhouse of Federal Rural University of Amazonia Belém, Pará, Brazil, located at $01^{\circ} 28^{\prime} 03^{\prime \prime}$ S; $48^{\circ} 29^{\prime} 18^{\prime \prime}$ W. For this study two cultivars of Vigna unguiculata (L.) Walp., BRS Guariba and BR3 Tracuateua (moderately tolerant and sensitive to salinity, respectively) from the Germplasm Bank of Embrapa Eastern Amazon were used. The biochemical and physiological analyzes were made in Laboratory of
Biodiversity Studies of Upper Plants (EBPS), belonging to the Institute of Agrarian Sciences (ICA) of the university campus.

\section{Nutrient solution, salt and brassinosteroids concentrations}

At 7 days after sowing (DAS), when the plants threw the first pair of leaves, the cowpea seedlings were transplanted to $1000 \mathrm{~mL}$ capacity pot-vessel cups containing $500 \mathrm{~mL}$ nutrient solution Hoagland and Arnon (1950) with $1 / 4$ of ionic strength in $\mathrm{pH} 5.5 \pm 0.5$. After the second pair of leaves, the solution was modified to $1 / 2$ of ionic strength. The 24 -epibrassinolid was purchased of the Sigma. It was dissolved in ethanol (1 $\mathrm{mg} \mathrm{ml}^{-1}$ ) diluted in this same solution.

The plants were subected to the treatment with brassinosteroids $(\mathrm{Br})$ in concentrations of 0.2 and $0.4 \mu \mathrm{M}$, and remained under this condition for 7 days for acclimation. After this period, the plants were subjected to the saline treatment $(\mathrm{NaCl})$ in the concentration of 50 and $100 \mathrm{mM}$ for 7 days. Treatments with doses of zero refers to the control treatment.

\section{Collection and storage of plant material}

The collection of the plants occurred at $24^{\text {th }}$ DAS, 04:30 AM. The determination of the relative water content was performed in vivo. On that occasion, primary leaves fully expanded from each of the repetitions, fresh, were reserved for determining the activity of nitrate reductase (NR) and electrolyte leakage (EL).

Subsequently, the leaves were wrapped in aluminum paper and stored in a freezer at $-80^{\circ} \mathrm{C}$. For the determination of biochemical analysis, the material was taken to the oven with ventilation of forced air of $65^{\circ} \mathrm{C}$ for $48 \mathrm{~h}$. After drying, the dry weight of the sheet was determined. The dried material was ground in mill to obtain a fine powder being properly stored in Falcon tubes until used in the assays.

\section{Relative water content and Electrolyte leakage}

The RWC was calculated according Slavick (1974), using the following formula:

$$
\text { RWC }(\%)=\frac{F W-D W}{\text { TW }- \text { DW }} \times 100
$$

Electrolyte leakage was determined by Blum and Ebercon (1981). $100 \mathrm{mg}$ of leaf was weighed separately, where they were stored in Falcon tubes with $10 \mathrm{~mL}$ of deionized water, remaining undisturbed for $6 \mathrm{~h}$ (room temperature; $25^{\circ} \mathrm{C}$ ). After that period, the electrical conductivity was measured (L1). Subsequently, the Falcon tubes were heated in water bath at $100^{\circ} \mathrm{C}$ for 1 hour and then the second reading was held (L2). EL was estimated by the equation:

$\mathrm{EL}(\%)=(\mathrm{L} 1 / \mathrm{L} 2) \times 100$

\section{Experimental design}

A completely randomized experimental design (DIC) was used in a $2 \times 3 \times 3$ factorial scheme, being two cowpea cultivars. Three brassinosteroid concentrations $(0,0.2$ and $0.4 \mu \mathrm{M} \mathrm{Br})$ and three concentrations of $\mathrm{NaCl}(0,50$ and 100 $\mathrm{mM} \mathrm{NaCl}$ ), composed of 4 replicates. 


\section{Nitrogen compounds}

\section{Content of $\mathrm{NO}_{3}^{-}$and nitrate reductase activity}

With the aid of a stainless steel driller foliar discs were collected in vivo, according to the method described by Hageman and Hucklesby (1971). Nitrate levels were determined according to Cataldo et al. (1975), in a reaction vial containing $100 \mu \mathrm{L}$ of extract and $200 \mu \mathrm{L}$ salicylic acid $5 \%$ solution $(w / v)$ in concentrated sulfuric acid.

\section{Content of Ammonium}

Free ammonium was determined using the method by Weatherburn (1967).

\section{Content of Soluble amino acid}

For the determination of total soluble amino acid, the method used was the second Peoples et al. (1989).

\section{Content of Soluble protein}

Determined by the method described by Bradford (1976).

\section{Content of Proline}

For this, we used the method described by Bates et al. (1973).

\section{Content of Glycine betaine}

The method utilized was according to Grieve and Grattan (1983).

\section{Statistical analysis}

The data were subjected to statistical analysis using analysis of variance (ANOVA) in Sisvar program version 5.4, and the averages compared by Tukey test at $5 \%$ probability.

\section{Conclusion}

The concentrations of brassinosteroids reversed the effect of saline stress on plants and the pathways of hormonal action were involved in the better efficiency of nitrogen metabolism by cultivars, in which the use of $0.2 \mu \mathrm{M}$ of 24epibsinolide enabled the acclimation of Vigna unguiculata $\mathrm{L}$. under saline stress, being the BR3 Tracuateua cultivar more expressive in most treatments.

\section{Acknowledgments}

The Institute of Agrarian Sciences, Laboratory of Biodiversity Studies of Upper Plants in Federal Rural University of Amazonia, Brazil and the funding institution: the National Council for Scientific and Technological Development (CNPq).

\section{References}

Adam G, Marquardt V (1986) Brassinosteroids. Phytochemistry. 25: 1787-1799.
Alves GAF (2010) Aspects ecophysiological, biochemical and growth of young yellow ipê plants [Tabebuia serratifolia (Vahl) Nicholson] in conditions of water deficit and flood. Doctoral thesis. Univ. Federal Rural da Amazônia, Belém, Brazil.

Anuradha S, Rao SSR (2003) Aplication of brassinosteroids to rice seeds (Oryza sativa L.) reduced the impact of salt stress on growth, prevented photosynthetic pigment loss and increased nitrate reductase activity. Plant Growth Regul. 40: 29-32.

Bagga S, Bracht J, Hunter S, Massirer K, Holtz J, Eachus R, Pasquinelli AE (2005) Regulation by let-7 and lin-4 miRNAs results in target mRNA degradation. Cell. 122: 553-563.

Bates LS, Waldren RPE, Teare ID (1973) Rapid determination of free proline for water-stress studies. Plant Soil. 39: 205207.

Blum A, Ebercon A (1981) Cell membrane stability as a measure of drought and heat tolerance in wheat. Crop Sci 21: 43-47.

Bradford MM (1976) A rapid and sensitive method for the quantitation of microgram quantities of protein utilizing the principle of protein-dye binding. Anal Biochem. 72: 248-254.

Grieve CM, Grattan SR (1983) Rapid assay for determination of water soluble quaternary ammonium compounds. Plant Soil. 70: 303-307.

Carlin SD, Santos DMM (2009) Physiological indicators of the interaction between water deficit and soil acidity in sugarcane. Pesq Agropec Bras. 44: 1106-1113.

Carvalho PA (2012) Nitrogen and carbon metabolism in rubber tree plants submitted to hypoxia and different sources of nitrogen. Doctoral thesis. Univ. Federal de Lavras, Lavras, Brazil.

Cataldo DA, Haroon SLE, Yougs VL (1975) Rapid colorimetric determination of nitrate in plant tissue by nitration of salicylic acid. Commun Soil Sci Plan. 6: 71-80.

Debouba M, Maâroufi-Dghimi $H$, Suzuki A, Ghorbel MH, Gouia H (2007) Changes in growth and activity of enzymes involved in nitrate reduction and ammonium assimilation in tomato seedlings in response to $\mathrm{NaCl}$ stress. Ann Bot. 99: 1143-1151.

Demiral T, Türkan I (2006) Exogenous glycinebetaine affects growth and proline accumulation and retards senescence in two rice cultivars under $\mathrm{NaCl}$ stress. Environ Exp Bot. 36: 29-38.

Frechill S, Lasa B, Ibarretxe L, Lamsfus C, Aparicio TP (2001) Pea responses to saline estress is affected by the source of nitrogen nutrition (ammonium or nitrate). Plant Growth Regul. 35: 171-179.

Frota KMG, Soares RAM, Arêas JAG (2008) Chemical composition of cowpea bean (Vigna unguiculata L. Walp.) cv. BRS-Milênio. Ciênc Tecnol Aliment. 28: 470-476.

Furtado GF, Junior JRS, Xavier DA, Andrade EMG, Sousa JRM (2014) Photosynthetic pigments and bean production Vigna unguiculada L. Walp. under salinity and nitrogen fertilization. Rev Verde. 9: 291-299.

Hageman RHG, Hucklesby DP (1971) Nitrate reductase from higher plants, in: Methods Enzymol. 17 A: 491-503.

Hamada K (1986) Brassinolide: some effects of crop cultivations. Plant Growth Regul. 15: 65-69.

Hasegawa PM (2013) Sodium $\left(\mathrm{Na}^{+}\right)$homeostasis and salt tolerance of plants. Environ Exp Bot. 92: 19-31. 
Horchani F, Ashi-Smiti, S (2010) Prolonged root hypoxia effects on enzymes involved in nitrogen assimilation pathway in tomato plants. Plant Signal Behav. 5: 15831589.

Kishor PBK, Sangam S, Amrutha RN, Sri Laxmi P, Naidu KR, Rao KRSS, Rao S, Reddy KJ, Theriappan P, Sreenivasulu N (2005) Regulation of proline biosynthesis, degradation, uptake and transport in higher plants: Its implications in plant growth and abiotic stress tolerance. Curr Sci. 88: 424-438.

Lin CC, Hsu YT, Kao CH (2002) The effect of $\mathrm{NaCl}$ on proline accumulation in rice leaves. Plant Growth Regul. 36: 275285.

Major I, Sales JC (2012) Climate Change and Sustainable Development. Available in <http://www.fdr.com.br/mudancasclimaticas/index.php> Access in: 30 dez. 2016.

Moro AL (2012) Relationship between silicon and water deficiency on biochemical and physiological aspects in rice. Doctoral thesis. Univ. Estadual Paulista, Botucatu, Brazil.

Munns R, Tester M (2008) Mechanisms of salinity tolerance. Annu Rev Plant Biol. 59: 651-681.

Nascimento SP, Bastos EA, Araújo ECE, Freire Filho FR, Silva EM (2011) Tolerance to water deficit in cowpea bean genotypes. Rev Bras Eng Agríc Ambient. 15: 853-860.

Ogawa K, Hiroyama K, Soutome R, Komamine A (2000) Coregulation of nitrate reductase and nitrite reductase in cultured spinach cells. J Plant Physiol. 157: 299-306.

Oliveira L (2010) Assimilation of nitrate in Campomanesia sp submitted to different conditions of water availability. Master's thesis. Univ. Federal de Goiás, Goiás, Brazil.
Peoples MB, Faizah AW, Reakasem BE, Herridge DF (1989) Methods for evaluating nitrogen fixation by nodulated legumes in the field. Aust Centre for Inter Agric Res Canb, p. 76.

Praxedes SC, Ferreira TM, Gomes Filho E (2009) Accumulation of proline and amino acids in cowpea bean cultivars with differential salinity tolerance. Caatinga. 22: 211- 214.

Sharma P, Bhardwaj R, Arora N, Arora HK (2007) Effect of 28homobrassinolide on growth, zinc metal uptake and antioxidative enzyme activities in Brassica juncea L. seedlings. Braz J Plant Physiol. 19: 203-207.

Slavick B (1974) Methods of studying plant water relations. Springer Verlang, p. 449.

Taiz L, Zeiger E (2013) Fisiologia Vegetal. 5. ed. Porto Alegre: ArtMed, $954 \mathrm{p}$.

Streit MN, Canterle LM, Canto, MW, Hecktheuer LHH (2005) The Chlorophylls. Cienc Rural. 35: 748-755.

Weatherburn MW (1967) Phenol hipochlorite reaction for determination of ammonia. Anal Chem. 39: 971-974.

Wei W, Bilsborrow PE, Hooley P, Lombi E, Forster BP (2003) Salinity induced differences in growth, ion distribution and partitioning in barley the cultivar Maythorpe and its derived mutant Golden Promise. Plant Soil. 250: 183-191.

Willians LE, Miller AJ (2001) Transporters responsible for the uptake and partitioning of nitrogenous solutes. Physiol Mol Biol Plants. 52: 659-688.

Zahran HH (1999) Rhizobium-legume symbiosis and nitrogen fixation under severe conditions and in a arid climate. Microbiol Mol Biol Rev. 12: 968-989.

Zullo MT, Adam G (2002) Brassinosteroid phytormones structure, bioactivity and applications. Braz J Plant Physiol. 14: 143-181. 